\title{
Comparative Analysis Of Employee Job Satisfaction In The Accounting Profession
}

\author{
Glen D. Moyes, (Email: fbmoyes@coba.panam.edu), University of Texas-Pan American \\ Lawrence P. Shao, (Email: shao@marshall.edu), Marshall University \\ Michael Newsome, Marshall University
}

\begin{abstract}
Evaluating job satisfaction among accounting professionals is an increasingly important area of concern for employers, which strive to recruit and retain quality employees and to improve their competitive positions. This study examines the results of surveys of accounting graduates from two AACSB International accredited universities from 1980 to 2003. Respondents were asked a variety of questions on job satisfaction as it relates to many factors including profession, firm size, certification, age, sex, race, advanced degrees and parent education. The findings of this study on job satisfaction provide benchmarks upon which accounting firms can use to evaluate job satisfaction levels among their own employees.
\end{abstract}

Key words: Job Satisfaction, Accounting Professionals, Caucasians and Hispanic Americans

\section{INTRODUCTION}

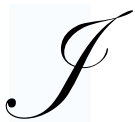

ob satisfaction describes how pleased an employee is with his or her position of employment. As the business environment in which firms operate becomes increasingly competitive, the level of employee satisfaction takes on added importance. In order to maintain consistency and continuity, firms are working hard to reduce the ever increasing problem of employee turnover. There are a variety of factors that can influence an employee's level of job satisfaction; some of these factors include the level of compensation and benefits, the use of equitable promotion systems, the overall working conditions, the style of management and the type of position itself including the tasks involved and the challenges the position generates.

The more motivated employees are the more satisfied they tend to be with their positions. Similarly, the happier employees are with their jobs, the more satisfied and productive they will be with their positions. Job satisfaction and motivation are closely linked. In addition, job design certainly can enhance job satisfaction and performance. Other factors that impact job satisfaction include management style, dedication of leadership and engagement and empowerment of employees. Thus, employee job satisfaction is an important attribute which must be regularly measured by companies. A typical way to measure job satisfaction is to use of rating scales where employees report their reactions to their jobs. Questions can address a wide variety of issues including compensation levels, work responsibilities, variety of tasks, promotional opportunities and the position itself. In this study, we use a similar survey rating scale to measure employee satisfaction.

The purpose of this study is to explore which of 78 factors may influence the level of job satisfaction of Caucasian and Hispanic American accounting professionals. Additionally, this study analyzes the relationships between these 78 job satisfaction factors and various demographic factors such as profession, firm size, certification, age, sex, race, advanced degrees and parent education.

The recruitment and retention of accounting professionals represents increasing problems for employers. Research projects conducted on job satisfaction of accounting professionals will enhance the understanding of which specific factors that may influence satisfaction on the job and hopefully help employers to recruit more accounting 
graduates and retain them longer as accounting professionals. This research study surveyed both accounting graduates (mostly Caucasian) from an AACSB regional university in New York city and accounting graduates (mostly Hispanic American) from another AACSB regional university in Texas. The respondents surveyed are accounting professionals who graduated with a bachelor degree in Accounting between 1980 and 2003.

An ideal example of recruiting and retention problems is public accounting. Public accounting firms seem to experience turnover problems with their accounting professionals. The five following issues (Larson, 1991) may contribute to this turnover problem. First, the communication between partners and staff accountants is poor concerning advancement opportunities within the firm and salary expectations of the staff. Second, accounting firms, especially the smaller ones, provide inadequate training on the job for new staff accountants who specialize in audit or tax areas. Third, partners and managers do not always provide performance evaluation information to staff accountants after they have completed audit engagements. Fourth, extensive travel required by staff accountants in public accounting causes conflicts with their families and friends. Fifth, staff accountants are required to work excessive overtime during tax season.

In the United States, the supply of accounting graduates has dropped significantly in the last decade. The total number of accounting graduates during the 2003-04 academic year was 53,760 compared to 60,620 during the 1993-94 academic year (AICPA, 2005). The demand for accounting graduates has only slightly declined over the same time period. The CPA firms in the United States hired in total 19,705 accounting graduates in 2004 compared 21,470 in 1994 (AICPA, 2005). The number of students graduating with bachelor degrees in Accounting has declined 73.2 percent since 1990 for four reasons (Billiot et al., 2004): relative decrease in entry-level accountant salaries, reduction in the quality of students majoring in Accounting, implementation of the 150-hour requirement for academic accounting programs and increments in freshman enrollments. The number of accounting graduates sharply decreased during the 1990s and started increasing slowly in the 2000s after passage of the Sarbanes-Oxley Act of 2002 (Puet, 2006). Myatt et al. (1997) indicated that two problems exist concerning accountants, especially Hispanic Americans: (1) recruiting them into the accounting profession, and (2) retaining them in the accounting profession. Similarly, Kraemer (2001) concluded that employee turnover was a direct result of job dissatisfaction. The purpose of this study is to investigate specific demographic information and 78 factors that may influence the level of job satisfaction of Caucasian and Hispanic American accounting professionals. The results of this study and other similar ones will help employers to enhance the job satisfaction of their accounting professionals, in order to increase the number of accountants hired and to increase the number of years that employers retain these professionals.

\section{LITERATURE REVIEW}

Job satisfaction among the accounting profession is an important issue employers must confront as they address an increasingly disturbing trend within the work environment --- increased levels of employee turnover. Recently, several studies have looked at this issued in an attempt to determine some common factors that contribute to employee turnover among accounting professionals. In order for accounting firms to effectively manage and retain their employees, they should pay particular attention to the importance of job satisfaction and how it affects the performance levels of their employees.

In an attempt examine job satisfaction among accounting professionals, researchers are examining many factors including firm size, certification, age, sex, race, and education levels. This is important since it can help establish benchmarks upon which accounting firms can use to evaluate job satisfaction among their employees. The concept of job satisfaction among accounting professional is starting to receive a significant amount attention. Never have the stakes in the examination of the quality of this concept been so high.

Many studies (Lankau and Scandura, 1996; McNeely, 1989; Bastell, 1981; and Chusmin and Koberg, 1990) indicated Hispanic employees as a minority group generally experience greater overall job satisfaction than Caucasian employees as the majority group. Hawkes et al. (1984a) found Hispanic employees experienced higher job satisfaction when accepted and respected by their peers, whereas Caucasian employees experienced more satisfaction from jobs with higher satisfaction. These cultural differences as to what are important for each group are indicative of the complexity of 
factors that may influence job satisfaction and retention for Caucasian majority and Hispanic minority groups.

Several studies (Beutell and Brenner, 1986; Beutel and Marini, 1995; and Lueptow et al., 1995) indicated at the impact of gender differences on employment values. Women put more relevance on intrinsic attributes the social and emotional aspects of place of employment, positive relations with peers, and job contentment. In comparison, men put more importance on extrinsic attributes such as high salaries and opportunity for advancement, job security and work independence. This distinction supported the preference that women tend to be nurses and teachers and men tend to be attorneys and doctors.

Age influences the relative importance that employees place on various work attributes. Wright and Hamilton (1978) younger employees value opportunities for promotion more than older employees whose opportunities for advancement decline with age. In a study by Aldag and Brief (1975), older employees seem to value jobs with meaningful content compared to younger counterparts.

College education may influence the level of job satisfaction. An article published in the Dallas Morning News (July 10, 2003) stated that according to the Department of Education, one-third of Hispanics dropped out of high school. As a result, when these children enter college, they have a great need for mentors and role models (de los Santos et al., 2002). A significant number of Mexican American students attending universities are first generation. Green (1992) found that first generation university students are attracted to majors contacted to professions such as accounting majors to accounting careers. Douvan (1976) found female students tend to decide on majors that lead to prestigious professions, when their own mothers worked outside of the home compared to mothers who are full-time homemakers. In addition, Leppel (2001) discovered first generation students tend to select business as a major, when their socioeconomic status, parent's education and father's occupation are all relatively low. With second generation students, the probability of choosing business as a major may decrease.

Berger (1986) studied satisfaction from job characteristics by sex and occupational type among Mexican American employees. He found that job satisfaction for Mexican American males was closely related to prestige, opportunities for advancement, and regularity of the job, while Mexican American females were most satisfied with their job's level of safety and freedom from health hazards. These differences were also found to be gender related.

In another study, Bersoff and Crosby (1984) research job satisfaction and family status. They learned that more than gender or job level, family status was the single best predictor of job attitudes among working women. When compared with married parents and married childless couples, single women were more dissatisfied with their jobs. George and Jones (1996) found that attainment of values in the work environment could have an affect in the areas of job performance and job satisfaction. They showed that attaining values at work becomes a prerequisite for satisfaction. Their findings showed that value attainment played an important role in determining job satisfaction and turnover. They learned that when positive mood was high, the relationship between job satisfaction and turnover intentions was quite high.

Gottfredson and Holland (1990) did a longitudinal analysis of the influence of congruence, job satisfaction, employee behavior and competency utilization. Results of their study showed that person-job congruence had significant positive correlations with job satisfaction. Thus, congruent work environments allowed employees to express interests and abilities, which led to more job satisfaction. Kraemer (2001) looked at employee turnover and the role of cultural mismatching. He learned that employee-employer attitudinal and value similarities were not only related to higher employee performance, but higher employee satisfaction as well. Job satisfaction is a crucial component in employee retention. He also found that job satisfaction on a daily basis was one of the biggest factors that influenced employee commitment. He concluded that employee turnover was a direct result of job dissatisfaction. Moch (1980) examined racial differences in job satisfaction. It was discovered that job satisfaction among Blacks, Hispanics, and Anglos were attributable to race. Hispanics and Blacks were underrepresented in management positions and were not favored in job assignments. Mexicans were found to be satisfied with their positions. 
Summers et al. (2000) examined the problem-solving styles of public accountants in consulting and audit functions. Consultants were, on average, more innovative in theft problem-solving style than auditors. A path analysis indicated that accounting professionals whose preferred problem-solving style did not fit the demands of the job experienced greater role stress. The additional stress negatively affected job satisfaction and organizational commitment. The results imply that matching an individual's problem-solving style to his or her functional role may help to minimize role stress and its attendant dysfunctional effects in public accounting.

Brierly (2000) assessed the relationship between professional examination performance in England and the accountants' perceptions of the level of their workload, attitudes of job satisfaction, organizational commitment and intention to leave the firm. He theorized that accountants' workload, job satisfaction, organizational commitment and intention to leave their firm were not related to professional examination performance. The results revealed no significant relationships between the variables and, hence, confirmed his hypotheses. Any attempt by firms of chartered accountants to change the work environment is unlikely to affect professional examination performance.

Amidst a flurry of assessment activity and demands for accountability, employers find themselves being judged on the work performance of their employees. The factors that may influence job satisfaction include firm size, certification, age, sex, race and education levels. Job satisfaction may vary from company to company, but the fact remains that a heightened level of scrutiny exists on job satisfaction among employees and how this impacts corporate performance. In light of the prior studies on job satisfaction, this study will investigate both 78 factors that may influence job satisfaction of Caucasian and Hispanic American accounting professionals and the demographic factors of these accounting professionals.

\section{METHODOLOGY}

\section{Questionnaire}

To collect data, the job satisfaction questionnaire was mailed to 2,000 Caucasian accounting graduates from a New York city university and 1,600 Hispanic American accounting graduates from a Texas university. Two mailings were conducted with each group of graduates. In Table 1, 150 usable questionnaires were received from the New York city accounting professionals (mostly Caucasian) representing 7.5 percent response rate, and 130 usable questionnaires were received from the Texas accounting professionals (mostly Hispanic American) representing 8.2 percent response rate. The job satisfaction questionnaires were lengthy which contributed to the lower response rates. In both surveys, the majority of the respondents were graduates from two doctoral and master's degree granting institutions. The figures show that more graduates from Caucasian majority university (150) than Hispanic majority university (130) answered the survey. Of the total completed surveys, the respondent response rate was higher for Hispanic graduates (70\%) than for Caucasian graduates (64\%). In total, 280 usable responses were used in this study to examine a variety of relationship among graduated working in the accounting profession.

Table 1

\section{Response Rates}

\begin{tabular}{|c|c|c|c|}
\hline & $\begin{array}{c}\text { New York } \\
\text { (Caucasian) }\end{array}$ & $\begin{array}{c}\text { Texas } \\
\text { (Hispanics) }\end{array}$ & Total \\
\hline Number of Graduates Contacted $^{1}$ & 2,000 & 1,600 & 3,600 \\
Total Complete Responses $^{\text {Total Usable Responses for this Study }}{ }^{2}$ & 235 & 186 & 421 \\
\hline
\end{tabular}

Notes: 1. New York university provided a list of 2,000 randomly drawn accounting graduates, from a total of approximately 8,000 . Texas university provided a list all 1,600 students, which includes all graduates of the accounting program. Two mailings were conducted at each university.

2. Only respondents currently working in the Accounting Profession are used in this study. 
Table 2

Characteristics of Respondents Working as Accountants

\begin{tabular}{|c|c|c|c|}
\hline Characteristic & (Caucasian) & $\begin{array}{c}\text { Texas } \\
\text { (Hispanic) }\end{array}$ & Tota \\
\hline Age (Years) & 32.0 & 37.4 & 34.5 \\
\hline Female (\% of Respondents) & 47.0 & 61.6 & 53.7 \\
\hline $\begin{array}{l}\text { Race }(\%) \\
\text { White } \\
\text { Hispanic } \\
\text { Other } \\
\end{array}$ & $\begin{array}{c}83.8 \\
10.7 \\
5.5 \\
\end{array}$ & $\begin{array}{c}19.2 \\
79.2 \\
1.6 \\
\end{array}$ & $\begin{array}{r}53.8 \\
42.5 \\
3.7 \\
\end{array}$ \\
\hline $\begin{array}{c}\text { Education (\% Having) } \\
\text { Bachelor Degree } \\
\text { Advanced Degree }^{1}\end{array}$ & $\begin{array}{l}82.0 \\
18.0\end{array}$ & $\begin{array}{l}88.5 \\
11.5\end{array}$ & $\begin{array}{l}85.0 \\
15.0\end{array}$ \\
\hline $\begin{array}{l}\text { Certifications (\% Having) } \\
\text { CPA } \\
\text { Other }^{2}\end{array}$ & $\begin{array}{c}48.0 \\
5.3\end{array}$ & $\begin{array}{c}22.3 \\
5.4\end{array}$ & $\begin{array}{c}36.1 \\
5.4\end{array}$ \\
\hline $\begin{array}{l}\text { Parent's Education }(\%)^{3} \\
\text { Less than High School } \\
\text { Bachelor Degree or Higher }\end{array}$ & $\begin{array}{l}10.0 \\
48.0\end{array}$ & $\begin{array}{l}40.8 \\
16.2\end{array}$ & $\begin{array}{l}24.3 \\
66.8\end{array}$ \\
\hline $\begin{array}{l}\text { Profession (\% Working As) } \\
\text { Public Accountant } \\
\text { Corporate Accountant } \\
\text { Government Accountant } \\
\text { Self-Employed Accountant }\end{array}$ & $\begin{array}{c}47.0 \\
49.3 \\
3.0 \\
0.8\end{array}$ & $\begin{array}{c}21.3 \\
36.1 \\
34.4 \\
8.2\end{array}$ & $\begin{array}{c}34.8 \\
43.0 \\
18.0 \\
4.3 \\
\end{array}$ \\
\hline $\begin{array}{l}\text { Employer Size (\% Working with) } \\
\text { Less than } 50 \text { Employees } \\
500 \text { or More Employees }\end{array}$ & $\begin{array}{l}10.7 \\
60.0\end{array}$ & $\begin{array}{l}35.4 \\
30.8\end{array}$ & $\begin{array}{l}22.1 \\
46.4\end{array}$ \\
\hline Fair Pay for Work (\% Agreeing $)^{4,5}$ & 74.7 & 63.1 & 69.3 \\
\hline Job Satisfaction (\% Satisfied $)^{5,6}$ & 88.0 & 91.5 & 89.6 \\
\hline Continue Working for Current Employer (\% Intending To $)^{5.6}$ & 79.3 & 84.6 & 81.8 \\
\hline
\end{tabular}

Notes: 1. Advanced degrees observed in the sample are MBA, MS-Accounting, JD, JD-MBA, and MS/MA-Other, and Other-NotSpecified.

2. Other certifications observed in the sample are CMA, CIA, CFP, CFA, and Other-Not-Specified.

3. The question is "What is the highest level of education completed by either your mother or father?"

4. The statement is "I feel I am being paid a fair amount for the work I do"

5. Respondents who Agreed Very Much, Agreed Moderately or Agreed Slightly were counted as Agreeing. Those who Disagreed Very Much, Disagreed Moderately or Disagreed Slightly was counted as Not Agreeing.

6. The correlation between Job Satisfaction and Continue Working for Current Employer is 0.3522, which is significant at the 0.05 level.

\section{Demographic Information}

For the demographical information in Table 2, the respondents from New York were mostly Caucasian, younger and more likely to earn a graduate degree, obtain the CPA license and work for corporations or CPA firms, which are considered large employers. In comparison, the respondents from Texas were mostly Hispanic American, older and more likely to be female and work for government or corporations, which are considered small employers. A major difference between the two institutions related to race. Almost 80 percent of the respondents from the Texas university were Hispanic, while 84 percent of the respondents from the New York university were Caucasian. Parent education for New York respondents was more likely to bachelor degree or higher and for Texas respondents was more likely to be high school or lower. 
Table 3

Definitions of Independent Variables Used in Ordered Logistic Models

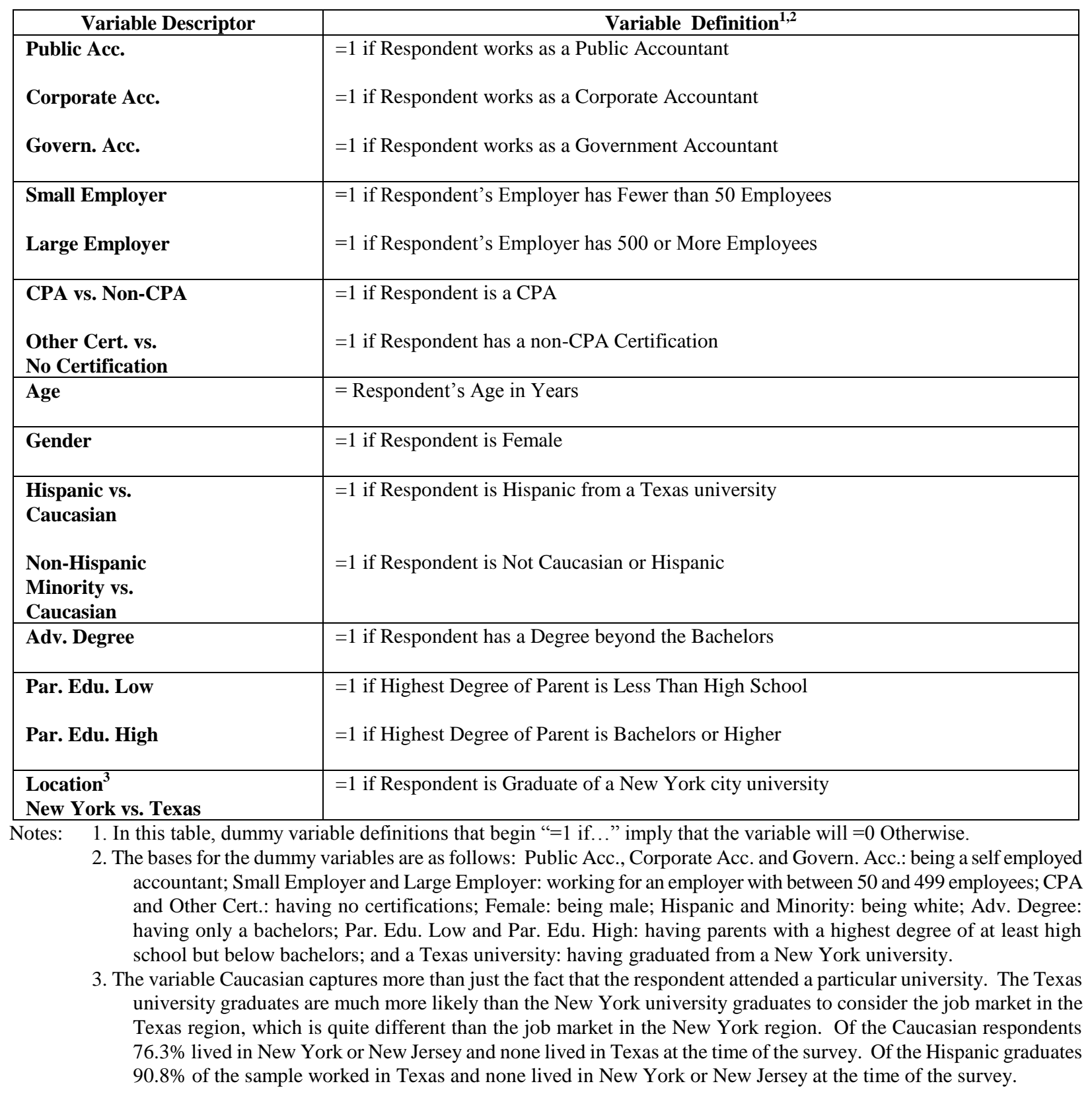

The Texas (mostly Hispanic) accounting professionals perceived slightly higher level of job satisfaction and are more likely to continue with their current employers than the New York (mostly Caucasian) counterparts. This finding is consistent with the prior studies by Lankau and Scandura, 1996, McNeely, 1989; Bastell, 1981; and Chusmin and Koberg, 1990. In contrast, New York respondents perceived receiving fair pay for work done more than Texas respondents. Interestingly, self-employment seems to occur more with Hispanics. 
Table 3 provides definitions of variables used in the ordered logistics. Variable descriptors included: type of accounting professional (public, corporate and government accountants), firm size (small and large employers), certification (CPA and other accounting certificates), age (actual number of years old), sex (female or male), race (Hispanic or Caucasian and non-Hispanic minority or Caucasian), advanced degrees (graduate degree or not), parent education (high school diploma or college graduate) and university location (New York city or Texas).

\section{Regression Models}

A series of logit regressions were run to determine how different respondent characteristics had significant effects on statements related to job satisfaction. To analyze the data, the variables (Table 3) including profession, firm size, certification, age, gender, race, advanced degrees, parent education and location were run as independent variables in logistic regressions on the dependent variables. The dependent variables were created from each of 78 job satisfaction statements listed on the questionnaire, with agreement being assigned a value of 1 and disagreement being assigned a value of 0 . Only those variables which were found to significantly affect agreement with one of the 78 statements at the 95 percent confidence level, using $\mathrm{z}$-scores, are reported in this paper.

\section{RESULTS}

\section{Type Of Accounting Professional}

Table 4 lists only the respondent characteristics that had significant effects on the statements related to accounting profession, size of employer and job satisfaction. The type of accounting professional fell into three groups: public accountant, corporate accountant and government accountant. The New York (mostly Caucasian) and Texas (mostly Hispanic) accounting professionals as respondents varied in their perceptions as to which factors influence their level of job satisfaction across the different types of employment within the accounting profession (public, private and government). In Table 4, both the New York and Texas respondents whose profession is public accounting are more likely to be satisfied with the benefits they receive, to like the people they work, and to feel the work they do is appreciated. Both the New York and Texas respondents whose profession is corporate accounting are less likely to feel isolated within their organizations, to work harder due to incompetence of their peers, to receive helpful performance feedback from their supervisors, and to have their employers promote understanding of racial/ethnic and religious groups. In corporate accounting, both groups are more likely to hear their work assignments are fully explained, to understand organizational goals clearly, and to be satisfied with benefits they receive. Both groups whose profession is governmental accounting are more likely to be prevented from doing a good work due to red tape, to experience bad communications within their organizations, to not hear helpful performance feedback, to be excluded from various team projects, and to have supervisors consider gender in making job assignments. The respondents in governmental accounting implied that their supervisor commit gender discrimination in making work assignments and exclude them from various team projects. Interestingly, both groups working in corporate and government accounting are more likely to receive provide helpful performance feedback from supervisors. Also, both groups in public and corporate accounting are less likely to receive helpful performance feedback from their supervisor. New York and Texas respondents in corporate accounting perceived more significant job satisfaction factors compared to those in either public or private accounting.

\section{Firm Size}

In Table 4, the firm size was determined by the total number of employees. Small employers had less than 50 employees, whereas large employers had more than 500 employees. In Table 4, New York and Texas accounting professionals who work for small employers compared to those with large employers are more likely to believe they do not receive enough benefits. In contrast, New York and Texas accounting professionals who work for large employers compared to those with small employers are more likely to accept opinions of members of work teams, to be included in various team projects, to consider the benefit package as being equitable and good as most other organizations offer, and to be able to do a good job in spite of many rules and procedures. In addition, both groups of accounting professionals working for large employers are more likely to believe that their organizations encourage and promote a general understanding of racial, ethnic and religious groups as well as encourage gender and racial diversity by providing 
meetings and workshops on cultural diversity. As a result, the New York and Texas respondents in large employers are more likely to feel that their peers do not treat them differently due to racial background. Both groups working for large employees perceived more positive job satisfaction factors than those in small employers.

\section{Table 4}

\section{Characteristics Having Significant Effects on Statements ${ }^{1,2}$ (Results of Logistic Regressions)}

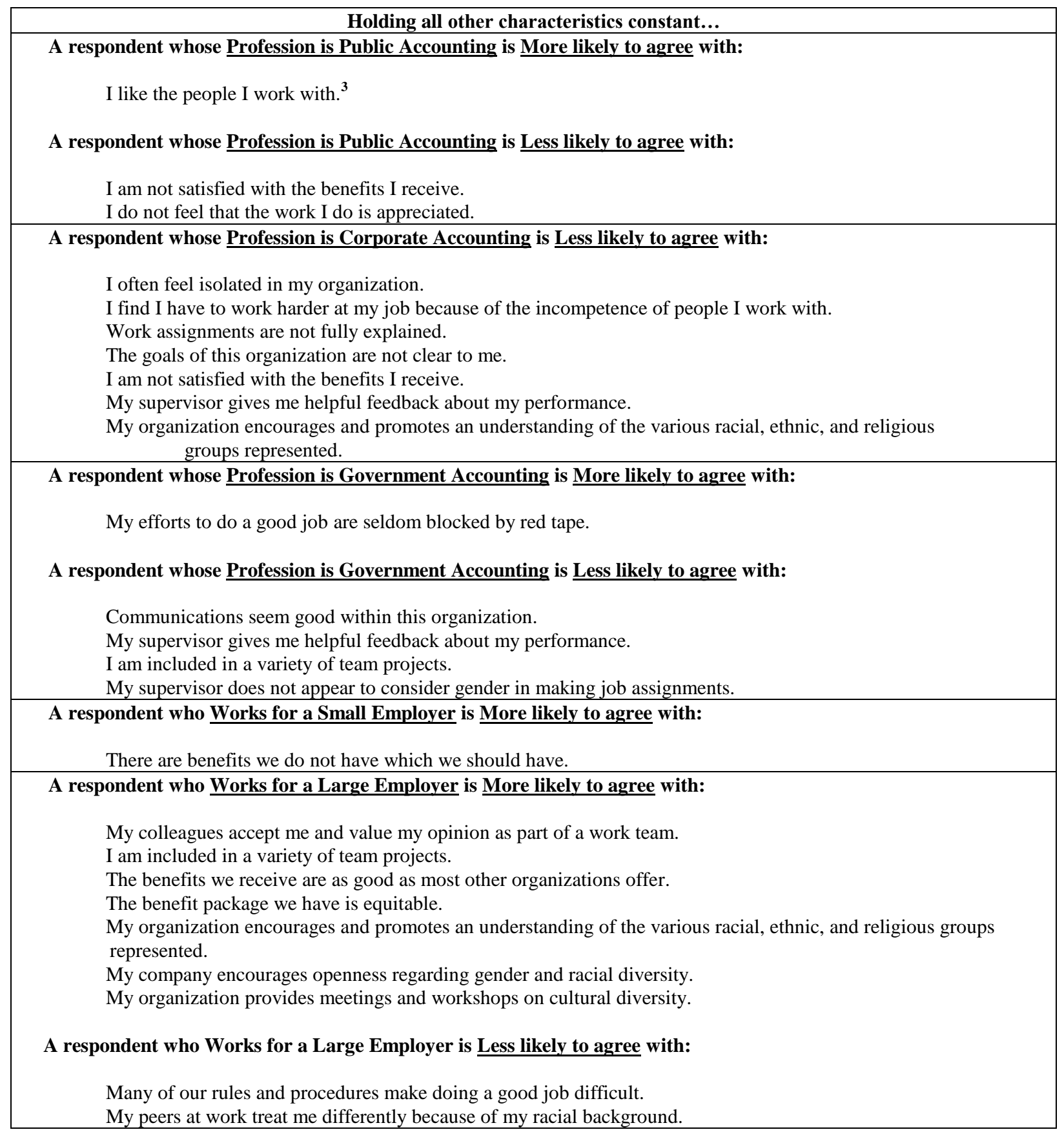




\section{Accounting Certification}

In Table 5, accounting certification was divided into two groups: Certified Public Accountants (CPAs) and Other Certification which includes Certified Management Accountant (CMA), Certified Internal Auditor (CIA), Chartered Financial Analyst (CFA), and Certified Financial Planner (CFP). Table 5 lists respondent characteristics of New York (mostly Caucasian) and Texas (mostly Hispanic) accounting professionals that had significant effects on the statements related to certification, age, sex and job satisfaction. In Table 5, both New York and Texas respondents who are CPAs compared to non-CPAs are more likely to feel isolated in their organizations, to perceive the work they do as being meaningless and unappreciated caused by both bad management attitudes and inadequate compensation, and to not understand the organizational goals clearly. Also, both groups as CPAs are more likely to be satisfied with their chances for promotion which seems to be as fast as with other employers. For both groups, CPAs are more likely to report any sexual harassment act committed by their supervisors and believe any discriminatory act would be investigated fairly by their employers than non-CPAs.

New York and Texas respondents with certification other than CPA such as CMA, CIA, CFA and CFP are more likely to be satisfied with their chances for promotion compared to Caucasians and Hispanics without accounting certification. At the same time, both groups are less likely to feel their peers interact with them as individuals and not as member a particular group, which implies racial discrimination may be occurring with the Hispanics. The two groups, whether they hold the CPA license or other certification (CMA, CIA, CFA, and CFP) are more likely to be satisfied with their chances for promotions compared to their counterparts without certification. All accounting certifications seem to enhance the probability of future promotions for both New York and Texas respondents.

\section{Age Of Accounting Professional}

The older New York and Texas accounting professionals rather than the younger ones are more likely to enjoy their jobs and intend to remain with their current employers and in the accounting profession, since they are satisfied with their choice of profession. In general, this finding is similar to a study by Aldag and Brief (1975), in which they found older employees seem to value jobs with meaningful content more than their younger counterparts. Both older groups are also more likely to accept the opinions of colleagues who are part of work teams and to believe that the benefits package is equitable, although both groups feel they should receive additional benefits from their employers. It seems older accounting professionals experience more job satisfaction than the younger ones.

\section{Gender Of Accounting Professionals}

The female New York (mostly Caucasian) and Texas (mostly Hispanic) compared to their male counterparts are less likely to be treated differently by peers or supervisors due to their gender, to be treated unfairly by their supervisors and to receive minimum interest and attention from their supervisors. Women being less likely to receive minimum interest/attention from supervisors agree with women placing more importance on intrinsic attributes, in particular the emotional aspects of employment (Beutell and Brenner, 1986; Brenner et al., 1988; Beutel and Marini, 1995; and Lueptow et al., 1995). Similarly, family status represents the single best predictor of job attributes for working women (Bersoff and Crosby, 1984), in that single women were more dissatisfied with their jobs than married couples with or without children. Also, both female groups are less likely than males to receive increased visibility from supervisors, to know how to succeed within their organizations, and to attend all meetings critically important for them and their peers. Finally, females were less likely to have the opportunities for promotion to be the same as other employees and to have their employers encourage understanding of racial, ethnic and religious groups than males. In a study by Berger (1986), opportunities for advancement were related to job satisfaction less for females and more for males, and another study by Pergamit and Veum (1999) concluded men were more likely to be promoted than women. Gender discrimination does not seem to be an issue, but employers may not be providing enough visibility, promotion opportunities, and understanding of minority groups to female accounting professionals which may represent a greater concern for Hispanic women. 
Table 5

\section{Characteristics Having Significant Effects on Statements ${ }^{1,2}$ (Results of Logistic Regressions)}

\begin{tabular}{|c|}
\hline Holding all other characteristics constant... \\
\hline A CPA is More likely to agree with: \\
\hline I often feel isolated in my organization. \\
\hline I do not feel that the work I do is appreciated. \\
\hline I sometimes feel my job is meaningless. \\
\hline The goals of this organization are not clear to me. \\
\hline I feel unappreciated by the organization when I think about what they pay me. \\
\hline People get ahead as fast here as they do in other places. \\
\hline I am satisfied with my chances for promotion. \\
\hline I am confident that any report of a discriminatory act would be handled fairly in my organization. \\
\hline I would not be afraid to report an act of sexual harassment against me to my supervisors. \\
\hline A respondent with a Certification Other than CPA is More likely to agree with: \\
\hline I am satisfied with my chances for promotion. \\
\hline A respondent with a Certification Other than CPA is Less likely to agree with: \\
\hline My peers interact with me as an individual and not as a member of a particular racial group. \\
\hline An Older respondent is More likely to agree with: \\
\hline My job is enjoyable. \\
\hline I intend to remain in the accounting profession. \\
\hline I intend to remain with my current employer. \\
\hline I am satisfied with my choice of profession. \\
\hline My colleagues accept me and value my opinion as part of a work team. \\
\hline The benefit package we have is equitable. \\
\hline There are benefits we do not have which we should have. \\
\hline A Female respondent is Less likely to agree with: \\
\hline My peers at work treat me differently because of my gender. \\
\hline My supervisor at work treats me differently due to my gender. \\
\hline My supervisor is unfair to me. \\
\hline My supervisor shows too little interest in the feelings of subordinates. \\
\hline My supervisor assigns me projects that increase my visibility in the organization. \\
\hline I am invited to attend all meetings to which employees at my level are invited. \\
\hline I know what it takes to succeed in my organization. \\
\hline My opportunity for promotion is the same as other employees in spite of my gender. \\
\hline $\begin{array}{l}\text { My organization encourages and promotes an understanding of the various racial, ethnic, and religious groups } \\
\text { represented. }\end{array}$ \\
\hline
\end{tabular}

\section{Hispanic Versus Caucasian Accounting Professionals}

Table 6 lists characteristics of accounting professionals that had significant effects on the statements related to ethnicity, accounting professional graduate degrees, parent education attainment and job satisfaction between all the Hispanics and all the Caucasians from both universities. In this section of the paper, the Hispanics presented 79.2 percent of accounting graduates from the Texas university and 10.7 percent of accounting graduates from the New York city university. Likewise, the Caucasians represented 83.8 percent of the accounting graduates from the New York city university and 19.2 percent of the accounting graduates of the Texas university. In Table 6, the Hispanic accounting professionals are more likely compared to their Caucasian counterparts to be satisfied with their present work environment and choice of career and to perceive very high job satisfaction, in that they look forward to going to work. 
Hispanics compared to Caucasians seem to feel accepted as members of the work teams and to receive helpful performance feedback from their supervisors and to know how to succeed with their organizations, which is somewhat confirmed by Laukau and Scandura (1996) whose finding was Hispanics feel more organizational commitment from their organizations. They also tended to believe communications is good within their organizations as well as their supervisors encourage openness concerning gender and racial diversity and do not consider gender in making job assignments. Ironically, Pergamit and Veum (1999) concluded that Caucasians were more likely to be promoted over Hispanics and African Americans. No gender issues seem to exist among the Hispanic accounting professionals, especially with the women. According to Moch (1980), job satisfaction among African Americans, Hispanics and Caucasians was attributable to race Hispanics and African Americans were underrepresented in management positions and were discriminated in job assignments. In general, Hispanics seem to experience higher levels of job satisfaction (Moch, 1980) than Caucasians, especially with more prestigious careers (Hawkes et al., 1984b).

\section{Non-Hispanic Minority Accounting Professionals}

In Table 6, non-Hispanic minority accounting professionals represent minority groups other than Hispanics. In other words, these non-Hispanic minorities are neither Caucasian nor Hispanic. These non-Hispanic minorities are 5.5 percent of the accounting graduates of the New York city university and 1.6 percent of the accounting graduates from the Texas university. In Table 6, the non-Hispanic minority accounting professionals compared to their Caucasian counterparts are more likely to be treated as members of a particular racial group and not as individuals by their supervisors, in that these non-Hispanic minorities do not feel as part of the dominant culture of their employers. When they do a good job, they are more likely to receive no recognition and to be blocked by red tape. These non-Hispanic minorities seem to be subjected to racial discrimination from their employers and to perceive less job satisfaction than Caucasians. Surprisingly, these non-Hispanic minorities are more likely to be adequately prepared on how to succeed in their organizations.

\section{Accounting Professionals With Advanced Degrees}

All New York (mostly Caucasian) and Texas (mostly Hispanic) accounting professionals surveyed graduated with a bachelor degree (majoring in Accounting). In addition, 18.0 percent of the Caucasians and 11.5 percent of the Hispanics graduated with advanced degrees (masters or doctorate). In Table 6, New York and Texas respondents with an advanced degree are less likely compared to their counterparts without advanced degrees to perceive very high job satisfaction, to intend to remain with their current employers and in the accounting profession, or to sense pride in doing their jobs. They seem to believe that many rules make doing a good job difficult and that their supervisors are considered unfair and do not assign them to projects that would increase their visibility within their organizations. Both groups with advanced degrees may experience may be less satisfied with their jobs, since they may have higher expectations than those with only bachelor degrees. Interestingly, Kranau et al. (1982) found Hispanic women who were highly educated were more likely to be acculturated, non-traditional, single and younger.

For New York and Texas respondents with advanced degrees, their peers may be less likely to interact with them as individuals and to treat them differently as members of particular racial groups than those without advanced degrees. Even, their supervisors may be unfair to them. Having graduate degrees partially contributes to employees being isolated with peers on the job but may enhance their chances for promotion if they perform well. Higher education may tend to increase individuals' expectations about their jobs that employers cannot satisfy and which peers with less education may resent.

In addition, parents exert influence in many or all aspects of the future careers of their children. Besides education level of parents, the occupation of parents can affect the general direction of the college education of their children. For example, Leppel (2001) found first generation children will more likely choose business as a major, in situations where family socioeconomic status, parent's education and father's occupation are all relatively below average. 


\section{Educational Level Of Accounting Professionals' Parents}

The parents of the both New York (mostly Caucasian) and Texas (mostly Hispanic) accounting professionals were classified into two groups: low educational attainment (high school diploma is highest degree) and high educational attainment (bachelor degree is the lowest degree). In Table 6, accounting professionals who had parents with low educational attainment compared to those with high educational attainment are more likely to be treated by peers differently than they treat others and to feel their employers provide adequate benefits. In society, people with lower levels of education may be accepted less by others. Such accounting professionals whose parents have lower educational levels are more likely to be Hispanic first generation students which possess a higher need for mentors and role models according to a study by de los Santos et al. (2002). In comparison, accounting professionals who had parents with higher education attainment compared to those with low educational attainment are more likely to believe that there are few reasons to work for their current employers such as low compensation, poor benefits, bad working conditions, unfair supervisors and incompetent peers, etc Parents with more education may teach their children to attain the highest level of education possible and to also expect the most from their employers as a result of their higher education.

\section{A Texas University Accounting Graduates Versus a New York City University Accounting Graduates}

Table 7 lists characteristics of accounting professionals that had significant effects on the statements related to race, advanced degrees, parent education, university location and job satisfaction between a Texas university and a New York city university. In Table 7, accounting graduates (Caucasian, Hispanic and non-Hispanic minority) who graduated from a Texas university compared to the accounting graduates (Caucasian, Hispanic and non-Hispanic minority) from a New York city university are less likely to look forward to going to work, to be accepted as part of work teams, to receive helpful performance feedback from their supervisors, to feel they are being paid a fair amount for the work they do, and to believe the benefit package is equitable and as good as most other employers offer. In addition, the Texas university graduates are less likely to be satisfied with their chances for promotion, to perceive the opportunities for promotion are considered the same as other employees in spite of my gender than the New York graduates. Finally, the Texas graduates are less likely to be invited to non-work activities (e.g. parties and lunch) and to encourage openness concerning gender/racial diversity by employers compared to the New York graduates. The one main difference between the two university accounting graduates is location. One group of accounting professionals graduated from a regional university in a large city (New York city) and the other group of accounting professionals graduated from a regional university in a small city (in Texas). Both universities are generally the same size based on the total number of students. In comparison, the Texas university accounting graduates seem to perceive lower levels of job satisfaction than the New York city university accounting graduates. It is natural that accounting professionals would prefer larger cities over smaller ones. In the larger cities, the accounting professionals will receive higher compensation, more intensive on the job training in, and greater opportunities for advancement. 
Table 6

\section{Characteristics Having Significant Effects on Statements ${ }^{1,2}$ (Results of Logistic Regressions)}

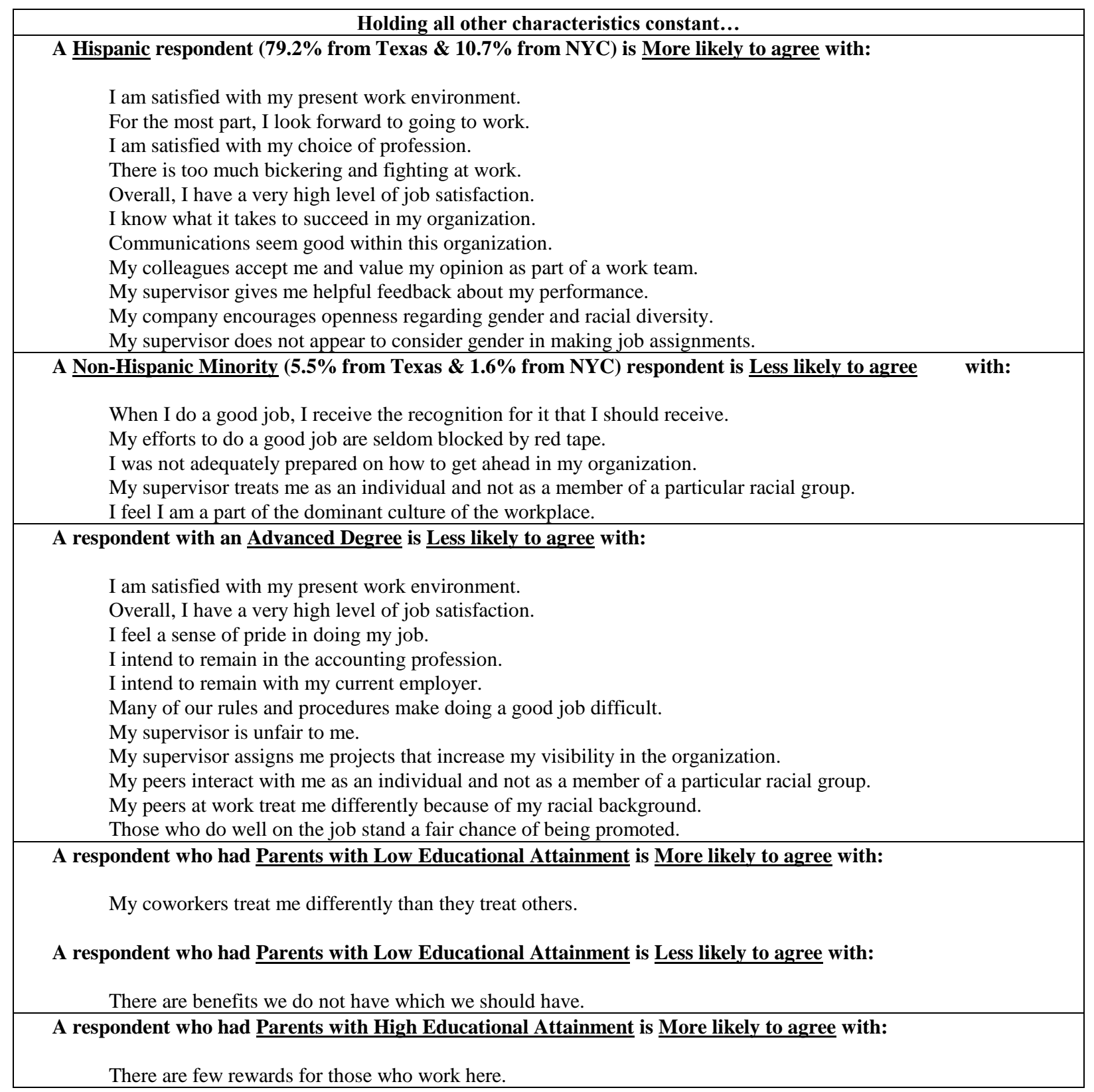


Table 7

\section{Characteristics Having Significant Effects on Statements ${ }^{1,2}$ (Results of Logistic Regressions)}

\begin{tabular}{|l|}
\hline Holding all other characteristics constant... \\
\hline A respondent who Graduated from a Texas university is Less likely to agree with: \\
For the most part, I look forward to going to work. \\
My colleagues accept me and value my opinion as part of a work team. \\
My supervisor gives me helpful feedback about my performance. \\
I feel I am being paid a fair amount for the work I do. \\
The benefits we receive are as good as most other organizations offer. \\
The benefit package we have is equitable. \\
I am satisfied with my chances for promotion. \\
My opportunity for promotion is the same as other employees in spite of my gender. \\
My colleagues invite me to non-work activities (e.g., parties, lunch). \\
My company encourages openness regarding gender and racial diversity.
\end{tabular}

Note:

1. The variables found in Table 3 were run as independent variables in logistic regressions on the dependent variables. The dependent variables were created from each of 78 job satisfaction statements, with agreement being assigned a value of 1 and disagreement being assigned a value of 0 . Only those variables which were found to significantly affect agreement with one of the 78 statements at the $95 \%$ confidence level, using z-scores, are reported here.

2. Statements which did not show significant differences across respondent characteristics included:

There is really too little chance for promotion on my job.

My supervisor is quite competent in doing his/her job.

Raises are too few and far between.

I like doing the things I do at work.

I have too much to do at work.

I enjoy my coworkers.

I often feel that I do not know what is going on with the organization.

I feel satisfied with my chances for salary increases.

I like my supervisor.

I have too much paperwork.

I don't feel my efforts are rewarded the way they should be.

My current job meets my preemployment expectations.

My current job is not as rewarding as I expected it to be.

I am satisfied with my choice of employer.

My supervisor at work treats me differently than other employees due to my racial background.

My supervisor watches my work more closely than that of others with similar experience.

I am given work assignments that best utilize and build my skills.

My supervisor involves me in the decision making process when appropriate.

I would not be afraid to report a discriminatory action against me to my superiors.

I feel as though my opinions and ideas are not treated with the same amount of respect as those of others.

I receive poor work assignments.

My supervisor does not appear to consider racial background in making work assignments.

3. This statement can be used as an example of how to read this table: If you take two accountants that are alike in every way (age, sex, race, education, etc), except that one works in public accounting and the other does not, the person working in public accounting is more likely to say "I like the people I work with."

\section{CONCLUSIONS}

Many factors were examined to determine their influence on job satisfaction among employees in the accounting profession. Variables such as accounting profession, employer size, certification, age, sex, race, advanced degrees, parent education and university location were analyzed to determine their impact on employee job satisfaction. The analysis shows some interesting findings. 
The accounting graduates from the New York university (mostly Caucasian) were younger and more likely to earn a graduate degree, obtain the CPA license and work for corporations or CPA firms which are considered large employers. In comparison, the accounting graduates from the Texas university (mostly Hispanic) were older and more likely to be female and work for government or corporations, which are considered small employers. The Hispanic accounting professionals perceived slightly more job satisfaction and are more likely to continue with their current employers than Caucasian counterparts. In contrast, Caucasians perceived receiving fair pay for work done more than Hispanics. Interestingly, self-employment seems to occur more with Hispanics.

Both New York and Texas respondents whose profession was public accounting were more likely to like the people they worked with and to feel the work they did was appreciated. The two groups whose profession was corporate accounting were less likely to feel isolated in their organizations and that their organization encouraged and promoted a general understanding of the various racial, ethnic, and religious groups within their organizations. Both groups whose profession was government accounting were more likely to be prevented from doing a good job caused by red tape and to experience bad communications throughout their organizations. The respondents in governmental accounting implied that their supervisors commit gender discrimination in making work assignments and exclude them from various team projects which increase visibility. Interestingly, New York and Texas respondents working in corporate and government accounting are more likely to receive provide helpful performance feedback from supervisors. Also, both groups in public and corporate accounting are less likely to receive helpful performance feedback from their supervisors.

When size of firm was considered, New York (mostly Caucasian) and Texas (mostly Hispanic) accounting professionals who work for small employers are more likely to feel that they should receive more company benefits. In comparison, both groups who worked for larger employers were more likely to be included and accepted in work team projects, to be satisfied with benefits offered by their employers, and to understand about racial/ethnic and religious groups as well as gender and racial diversity resulting from organizations providing meeting/workshops on cultural diversity. Large employers offer more positive job satisfaction factors to accounting professionals than small employers.

New York and Texas respondents with the CPA license felt that they were isolated, their performance was unappreciated, and their jobs were meaningless, although they were satisfied with their chances for promotion. Besides the CPA license, both groups who held other accounting certifications (CMA, CIA, CFA and CFP) are also satisfied with their chances for promotion. Unfortunately, they perceive their peers do not treat them as individuals but rather as members of a particular racial group, which implies racial discrimination against Hispanics.

Older New York and Texas accounting professionals tended to enjoy their jobs and remain in the accounting profession and with their current employers more than their younger counterparts. In addition, the two older groups seem to be more satisfied with benefits and more accepted as members of work teams. Older accounting professionals experience more job satisfaction than younger counterparts.

Female New York and Texas respondents felt their peers and supervisors did not treat them differently due to their gender. Unfortunately, female accounting professionals seemed to not receive adequate visibility from their supervisors by assigning them to important projects within the organizations. Additionally, supervisors are not showing enough interest and attention towards these women in the form of feedback, support and mentoring. Finally, they have low promotion opportunities and do not know how to succeed within their organizations. It seems the supervisors may be ignoring the professional needs of female accounting professionals. Hispanic accounting professionals compared to their Caucasian counterparts felt very high job satisfaction especially with their present work environment and profession. They felt their colleagues accepted them and their supervisors provided them with helpful performance feedback in that they know how to succeed within their organizations. Their supervisors encourage openness concerning gender and racial diversity and do not consider gender in making job assignments. There seems to be no gender or racial issues among the Hispanic accounting professionals.

Non-Hispanic minority accounting professionals compared to their Caucasian counterparts did not feel they received enough recognition for their work. In addition, they are treated by their supervisors as if they are members of particular racial group and not as individuals. It seems non-Hispanic minorities are discriminated by employers similarly. 
New York and Hispanic respondents with advanced degrees were not as satisfied with their present work environment and did not have a high level of job satisfaction compared to those with only bachelor degrees. In fact, they were less likely to remain with their current employers and in the accounting profession as a whole. Their supervisors may be unfair to them, and peers may treat them differently. Advanced degrees may partially alienate accounting professionals, because employees with graduate degrees may have higher expectations than those with only bachelor degrees.

New York and Texas accounting professionals who had parents with low educational attainment felt their coworkers treat me differently than they treat others. Individuals with low levels of education may not be accepted as much as people with higher education levels. Accounting professionals whose parents had attained higher education levels may have motivated their children to pursue higher education levels and expect more from employers.

Accounting graduates (Caucasian, Hispanic and non-Hispanic minority) who graduated from a Texas university compared to the accounting graduates (Caucasian, Hispanic and non-Hispanic minority) from a New York city university are less likely to look forward to going to work, to feel they fair compensation, to perceive acceptance as part of work teams, to believe their benefits are and adequate, to receive helpful performance feedback, and to be satisfied with promotion opportunities. Accounting professionals who graduated from a regional university in a large city seem to perceive more job satisfaction than accounting professionals who graduated from a regional university in a small city. The location difference indicates more advantages and opportunities exist in large cities compared to small cities.

This study presents a comparison of accounting graduates from two large universities, in which they were asked to provide their opinions concerning how important different factors may influence their level of employee job satisfaction. The findings show that the evaluation of overall job satisfaction is influenced by many factors including accounting profession, employer size, certification, age, sex, race, advanced degrees, parent education and location.

The results show that there are differences between what respondents feel influences their level of satisfaction on the job. Employers need to be cognizant of the factors that impact employee satisfaction and implement corporate policies that can enhance employee performance. Kraemer (2001) found job satisfaction is a critical component in employee retention. Furthermore, better benefit packages are an important consideration for motivating employees. Reward systems that recognize and promote high performance levels can have a positive impact within the accounting profession.

\section{REFERENCES}

1. Aldag, R.J. and A.P. Brief. 1975. Age and reactions to task characteristics. Industrial Gerontology 2: 223229.

2. American Institute of Certified Public Accountants (AICPA). 2005. The Supply Of Accounting Graduates And The Demand For Public Accounting Recruits-2005 For The Academic Year 2003-2004. Academic and Career Development Team. Jersey City, NJ: 1-57.

3. Bastell, A.P. 1981. Race differences in job satisfaction: a reappraisal. Journal of Human Resources (February): 291-294.

4. Berger, P.S. 1986. Differences in importance of and satisfaction from job characteristics by sex and occupational type among Mexican American employees. Journal of Vocational Behavior 28 (3): 203-213.

5. Bersoff, D., and F. Crosby. 1984. Job satisfaction and family status. Personality and Social Psychology Bulletin 10 (1): 79-83.

6. Beutel, A.M. and M.M. Marini. 1995. Gender and values. American Sociological Review 60: 436-448.

7. Beutell, N.J. and O.C. Brenner. 1986. Sex differences on work values. Journal of Vocational Behavior 28 (1): 29-41.

8. Brenner, O.C., A.P. Blazini, and J.H. Greenhaus. 1988. An examination of race and sex differences in managerial work values. Journal of Vocational Behavior 32 (3): 336-344.

9. Billiot, M.J.; S. Glandon and R. McFerrin. 2004. Factors affecting the supply of accounting graduates. Issues in Accounting Education (November) 19 (4): 443-468. 
10. Brierly, J. A. 2000. An analysis of the impact of the work environment on chartered accountants' professional examination performance. Journal of Social Psychology 140 (3): 397-398.

11. Chusmir, L.H. and C.S. Koberg. 1990. Ethnic differences in the relationship between job satisfaction and sex-role conflict among Hispanic and non-Hispanic white individuals. Psychological Reports 568-578.

12. Dallas Morning News. 2003. White house, groups promote Hispanic education (July 10).

13. de los Santos, G., E.C. Hume, and A.C. Cortes. 2002. Improving the faculty's effectiveness in increasing the success of Hispanic students in higher education - pronto! Journal of Hispanic Higher Education 1 (3): 225-237.

14. Douvan, E. 1976. The role of models in women's professional development. Psychology of Women Quarterly 1: 5-15.

15. George, J.M. and G.R. Jones. 1996. The experience of work and turnover intentions: Interactive effects of value attainment, job satisfaction, and positive mood. Journal of Applied Psychology 3: 318-325.

16. Gottfredson, G.D. and J.L. Holland. 1990. A longitudinal test of the influence of congruence, job satisfaction, competency utilization, and counterproductive behavior. Journal of Counseling Psychology 34 (4): 389-398.

17. Green, K.C. 1992. After The Boom: Management Majors In The 1990s. New York, NY: McGraw-Hill.

18. Hawkes, G.R., G.A. Guagnano, C. Acredolo, and S.A. Helmich. 1984a. Status inconsistency and job satisfaction: general population and Mexican American sub-population analysis. Sociology and Social Research (March) 378-387.

19. Hawkes, G.R., G.A. Guagnano, J.W. Smith, and M.K. Forest. 1984b. Power structure in Mexico and Mexican-American farm labor families. Journal of Applied Psychology

20. 59: 705-711.

21. Kraemer, W.F. 2001. Employee turnover: the role of cultural mismatching. Self-Management 52: 249262.

22. Kranau, E.J., V. Green, and G. Valencia-Weber. 1982. Acculturation and the Hispanic woman: Attitudes toward women, sex role attribution, sex role behavior and demographics. Hispanic Journal of Behavioral Sciences 4 (1): 21-40.

23. Lankau, M.J. and T.A. Scandura. 1996. An examination of job attitudes of white, black and Hispanic nurses in a public hospital. International Journal of Public Administration 19 (3): 377-398.

24. Larson, J.W. 1991. The view from the bottom of the ladder: Firms that understand their staff's concerns will have fewer turnover problems. Journal of Accountancy. 17 (2): 30-33.

25. Leppel, K. 2001. Race, Hispanic ethnicity, and the future of the college business major in the united states. Journal of Education for Business (March/April).

26. Lueptow, L.B., L. Garovich, and M.B. Lueptow. 1995. the persistence of gender stereotypes in the face of changing sex roles evidence contrary to the sociocultural model. Ethology and Sociology 16: 509-530.

27. McNeely, R.L. 1989. Job satisfaction and other characteristics among Hispanic-American human service workers: social casework. The Journal of Contemporary Social Work (April): 237-342.

28. Moch, M.K. 1980. Racial differences in job satisfaction: Testing four common explanations. Journal of Applied Psychology 65 (3): 299-306.

29. Myatt, P.G., J.S. Omumdson, R.G. Shroeder, and M.B. Stevens. 1997. The impact of Anglo and Hispanic ethnicity, gender, position, personality and job satisfaction on turnover intentions: a path analysis investigation. Critical Perspective on Accounting 8: 657-683.

30. Pergamit, M.R. and J.R. Veum. 1999. What is a promotion? Industrial and Labor Relations Review (July) 52 (4); 581-601

31. Puet, T. 2006. Number of accounting graduates rebounding from slow period. Columbus Business First (June 9). http://www.bizjournals.com/columbus/stories/2006/12/focus4.html.

32. Summers, S.L., J.T. Sweeney, and C.M. Wolk. 2000. Type A personality, job satisfaction, and turnover intention among certified public accountants. Journal of Information Systems 14 (1): 1-15.

33. Wright, J.D. and R.F. Hamilton. 1978. Work satisfaction and age: some evidence for the 'job change' hypothesis. Social Forces 56: 1140-1158. 
NOTES 